Бодэ Андрей Борисович (Москва). Кандидат архитектуры, советник РААСН. Заведующий сектором «Деревянное зодчество» Научно-исследовательского института теории и истории архитектуры и градостроительства (филиал ФГБУ «ЦНИИП Минстроя России») (111024, Москва, ул. Душинская, д. 9. НИИТИАГ). Эл. почта: bode-niitag@yandex.ru.

Жигальцова Татьяна Валентиновна (Архангельск). Кандидат философских наук. Доцент кафедры культурологии и религиоведения Северного (Арктического) федерального университета имени М.В. Ломоносова (163002, Архангельск, набережная Северной Двины, д. 17. САФУ им. М.В. Ломоносова). Эл. почта: zhitava@gmail.com.

Bode Andrei B. (Moscow). PhD in Architecture, Advisor of RAACS. Head of the Wooden Architecture Sector at the Research Institute of Theory and History of Architecture and Urban Planning (9 Dushinskaya st, Moscow, 111024. NIITIAG), branch of the Central Institute for Research and Design of the Ministry of Construction and Housing and Communal Services of the Russian Federation (TsNIIP), architect and restorer. Email mail: bode-niitag@yandex.ru.

Zhigaltsova Tatiana V. (Arkhangelsk). PhD in Philosophy, Associate Professor, Northern (Arctic) Federal University named after M.V. Lomonosov, Department of Cultural and Religious Studies (17, Severnaya Dvina embankment, Arkhangelsk, 163002). Email: zhitava@gmail.com.

๑ Бодэ А.Б., Жигальцова Т.В., 2021. Academia. Архитектура и строительство, № 4, стр. 13-21.

\title{
Общерусские влияния в деревянном зодчестве Беломорья XVII-XVIII веков на примере Вознесенской церкви села Кушереки
}

\section{А.Б.Бодэ, НИИТИАГ, Москва Т.В.Жигальцова, САФУ, Архангельск}

Статья посвящена архитектуре одного из выдающихся памятников деревянного зодчества XVII века - Вознесенской церкви села Кушереки, ярко и отчётливо представляющей архитектурные традиции Беломорья. Исследование нацелено на выявление взаимосвязей общерусских архитектурных влияний и региональных традиций. В задачи входит изучение архитектурных особенностей объекта в контексте развития региональных архитектурных традиций, сопоставление местного и общерусского, выявление направлений влияния архитектуры центральной России на формирование архитектуры регионов. В работе используются методы исторического, сравнительнотипологического анализа и в итоге - метод обобщения.

Рассматривается история места, где построен объект, и его значение в системе расселения Беломорья. Исследуются строительные этапы объекта и изменения, происходившие со временем. Выявляются особенности его архитектуры в соответствии с региональными традициями. Проводится сопоставление особенностей архитектуры объекта с аналогами. Делаются выводы о типичном и индивидуальном в архитектуре объекта. На примере Вознесенской церкви исследуется влияние общерусской архитектуры второй половины XVII века на традиции деревянного храмового строительства Беломорья. Делаются выводы об общем образном соответствии архитек-

\footnotetext{
*) Исследование осуществлено в рамках Программы фундаментальных научных исследований Российской академии архитектуры и строительных наук и Министерства строительства и жилищно-коммунального хозяйства Российской Федерации на 2021 год.
}

туры Беломорья и архитектуры центральных регионов страны и о конкретно-формальном сходстве деталей и локальных форм.

Рассматриваются другие постройки села Кушереки - Успенская церковь и колокольня. В их архитектуре отмечаются признаки местных традиций и соответствие общерусским влияниям.

Внимание заостряется на реставрации Вознесенской церкви, произведённой в 1970-х годах. Даётся оценка реставрационного решения с точки зрения современных тенденций в реставрационной практике памятников деревянного зодчества.

Новизна материала заключается во введении в научный оборот новых фактов по истории и архитектуре Беломорья, в новом осмыслении развития региональных традиций под воздействием влияний из центра страны. Раскрывается картина формирования традиции строительства деревянных кубоватых церквей Беломорья ${ }^{*}$.

Ключевые слова: русское деревянное зодчество, деревянные церкви, региональные традиции, общерусские влияния

All-Russian Influences in the Wooden Architecture of the White Sea of the 17th - 18th Centuries on the Example of the Church of the Ascension in the Village of Kushereka

A.B.Bode, NIITIAG, Moscow

T.V.Zhigaltsova, NArFU, Arkhangelsk

The article is devoted to the architecture of one of the outstanding monuments of wooden architecture of the XVII century - the Church of the Ascension in the village of 
Kushereka, vividly and distinctly representing the architectural traditions of the White Sea. The research is aimed at identifying the interrelationships of all-Russian architectural influences and regional traditions. The tasks include studying the architectural features of the object in the context of the development of regional architectural traditions, comparing local and allRussian, identifying the directions of influence of architecture in central Russia on the formation of regional architecture. The work uses methods of historical, comparative, and typological analysis and, as a result, the method of generalization.

The history of the place where the object was built and its significance in the settlement system of the White Sea are considered. The construction stages of the object and the changes that occurred over time are investigated. The features of its architecture in accordance with regional traditions are revealed. A comparison of the architectural features of the object with its analogs is carried out. Conclusions are drawn about the typical and individual in the architecture of the object. Using the example of the Ascension Church, the influence of the allRussian architecture of the second half of the XVII century on the traditions of wooden temple construction in the White Sea region is investigated. Conclusions are drawn concerning the general figurative correspondence of the architecture of the White Sea and the architecture of the central regions of the country and about the concrete-formal similarity of details and local forms.

Other buildings of the village of Kushereka are considered - the Church of the Ascension and the bell tower. Their architecture shows signs of local traditions and compliance with all-Russian influences. Attention is focused on the restoration of the Church of the Ascension, made in the 1970s. The assessment of the restoration solution is given from the point of view of modern trends in the restoration practice of monuments of wooden architecture. The novelty of the material lies in the introduction into scientific circulation of new facts on the history and architecture of the White Sea, in a new understanding of the development of regional traditions in response to the influences from the center of the country. The picture of the formation of the tradition of building wooden cubed churches of the White Sea region is revealed.

Keywords: Russian wooden architecture, wooden churches, regional traditions, all-Russian influences.

Архитектура регионов России, впрочем, как и любой другой страны, складывалась на основе привнесённой из центра и преобразовавшейся под влиянием местных условий, исторических, географических, этнических или иных факторов.

Деревянное зодчество Русского Севера отличается разнообразием местных традиций. Культурные влияния из центрально-русских земель шли на Север основными торговоэкономическими путями, которые пролегали по крупнейшим рекам: Онеге, Северной Двине, Сухоне, Свири.
Онега выделяется тем, что она была наиболее активным торговым путём в ранний период объединённого Московского государства, когда северорусские земли перешли от Новгорода к Москве [1, с. 50-51]. Через Вологодские и Белозёрские земли и далее по реке Онеге пролегал кратчайший путь из среднерусских земель к Белому морю. Это обусловило рост в XVI-XVII веков городов Белозёрска, Каргополя и основание новых крепостей-острогов Турчасова и Усть-Моши на Онеге [2, с. 317-329].

Одним из важнейших торговых и экономических узлов было устье Онеги. Существовавшее здесь поселение упоминается в Уставной грамоте князя Святослава Ольговича 1137 года. Возможно, это был Порожский погост, располагавшийся примерно в 20 км от моря [3, с. 32]. Более поздние исторические свидетельства относятся к Устьянской волости, на месте которой ныне находится город Онега. Здесь во второй половине XVII века был построен грандиозный храмовый комплекс, состоящий из Успенского собора, Никольской церкви и колокольни [4, с. 157-159].

Архитектура устьянского храмового комплекса как нельзя более ярко отражает традиции поонежского и поморского храмового строительства. Успенский собор, высота которого достигала 45 м, завершался кубом с пятиглавием, а стороны крещатого основания - бочками, увенчанными дополнительными главами. Никольская церковь также имела кубоватое пятиглавое завершение. Ансамбль устьянских храмов - декоративный, многоглавый, насыщенный пластикой, и в этом вся суть поморско-онежских архитектурных традиций. Шатры в них тоже присутствуют, но не главенствуют, а своей лаконичностью словно усиливают криволинейность и пластику форм.

Традиция строительства церквей с кубоватыми завершениями известна со второй половины XVII века [5, с. 255]. Самым ранним известным образцом типологически сложившегося кубоватого храма является Вознесенская церковь (1669) в поморском селе Кушереке. Её особенностями, ставшими типичными для кубоватых церквей, были: высокий стройный четверик, крупный куб, превышающий по ширине четверик, пятиглавие, обработка декоративными кокошниками.

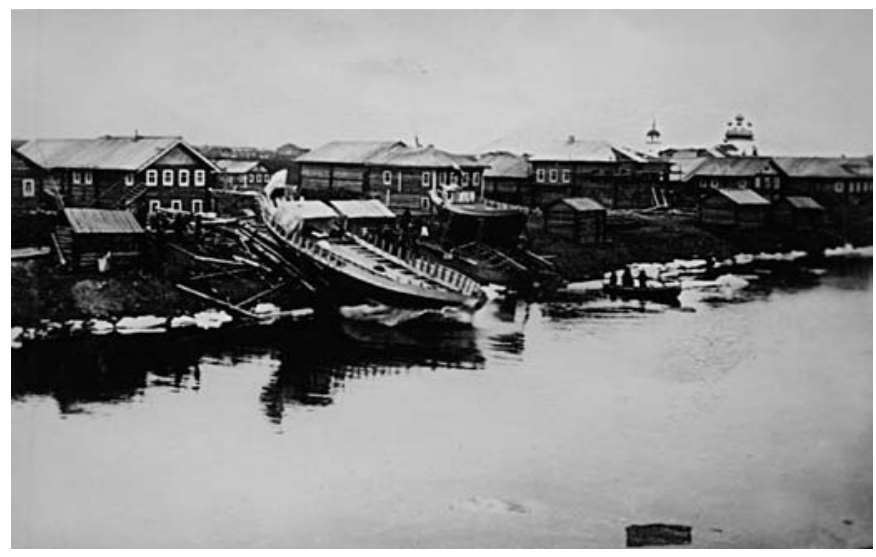

Рис. 1. Село Кушерека. Вид на Вознесенскую церковь в селе Кушереке. Фото середины ХХ века из личного архива А.П. Ефремова 
Судьба Вознесенской церкви достаточно сложная. В XIX веке она сильно перестраивалась и изменила свой первоначальный облик. Когда в 1970-х годах её перевозили под Архангельск в музей «Малые Корелы», взяли только древнюю часть, а позднейшую часть оставили на месте [6, с. 59-70]. В итоге при реставрации памятник наполовину потерял в подлинности. Рассмотрим подробнее историю и архитектуру кушерецкой церкви.

Поморское село Кушерека располагалось на берегах реки Куши и состояло из деревень Кузьминской и Логинской, которые, в свою очередь, делились на части, имевшие свои названия. По данным 1898 года село состояло из следующих частей: Верховье (23 дома), Гора (25 домов), Бачина (12 домов), Низ/Низовье (86 домов), Остров (32 дома) ${ }^{1}$. Таким образом, село Кушерека представляло собой приречный гнездовой тип поселения. Сохранилась легенда о выборе места для строительства Вознесенской церкви. Для этого пустили по воде бревно, и оно уперлось в противоположный берег, где тогда ещё не было застройки. Там и возвели церковь, возле которой со временем образовалась часть села Бачины, имевшая традиционную рядовую планировку (рис. 1).

Архивных исторических документов по Кушерецкому приходу несколько больше, чем по соседним приходам Малошуйскому, Нименьгскому, поскольку приход вызывал тревогу у Архангельской Духовной консистории в связи с большим количеством проживавших в нём старообрядцевбеспоповцев Даниловского толка.

В 1830 году село Кушерека насчитывало 138 дворов (442 мужчины и 491 женщина), из них раскольничьих - 3 дома (33 мужчины и 71 женщина) $)^{2}$. В 1844 году - 131 двор (502 мужчин и 572 женщин), из них раскольников: 46 мужчин и 87 женщин ${ }^{3}$. К середине века в Кушереке насчитывается 137 домов (чуть больше, чем в соседних сёлах), число мужчин и женщин превысило тысячу (533 мужчин и 642 женщин,

${ }^{1}$ ГААО Ф. 462. 0п. 1. Д. 35. Л. 16. Список населённых мест 1-го благочиния Онежского уезда, 1898.

2 ГААО. Ф. 29. 0п. 35. Д. 19. Л. 155. Клировые ведомости церквей Онежского уезда, Пинежского, Мезенского уездов / Ведомость учинена Благочинным Малошуйского Прихода Священником Симеоном Молчановым о благосостоянии Церквей и поведения Священно и церковнослужителей, 1830.

${ }^{3}$ ГААО. Ф. 29. 0п. 37. Д. 95. Л. 17. Клировая ведомость церквей Онежского уезда, 1844.



Рис. 2. Вознесенская церковь из села Кушереки. Вид с запада. Музей «Малая Корела». Фото Т.В. Жигальцовой

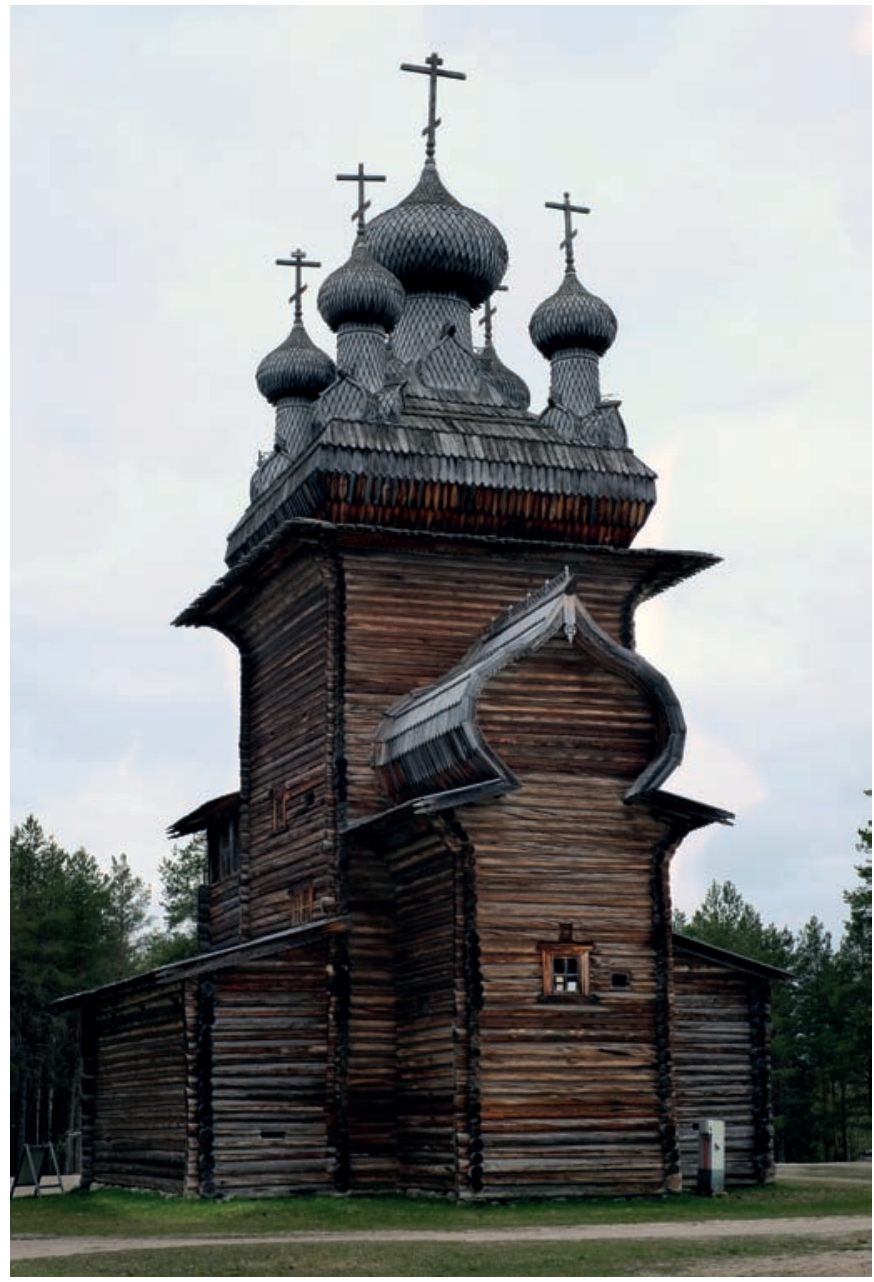

Рис. 3. Вознесенская церковь из села Кушереки. Вид с востока. Музей «Малая Корела». Фото Т.В. Жигальцовой 
раскольников 39 мужчин и 63 женщины $)^{4} .26$ июня 1889 года в селе сгорело 109 дворов ${ }^{5}$. Память об этом событии сохранилась до настоящего времени. Говорят, начало гореть с Горы, огонь перекинулся на ту сторону, до церкви, и та сторона полностью выгорела до Бачинской деревни. Местный священник составлял пятигодичные ведомости о состоянии православия и раскола в Кушерецком приходе. К концу XIX века население деревни еще более возросло. В 1889 году в приходе общее число душ: 703 мужских и 819 женских ${ }^{6}$. Таким образом, село Кушерека выделялось среди окрестных поселений величиной. В настоящее время село является заброшенным, в летнее время там проживает несколько семей.

Строительство Вознесенской церкви принято датировать 7177 (1669) годом ${ }^{7}$. Антиминс на полотне от 6 сентября 1669 году был освящён Ювеналием Епископом Архангельским и Холмогорским ${ }^{8}$. Вероятнее всего, это была вторая церковь, построенная на том месте, поскольку в самых ранних обнаруженных нами документах конца XVIII века указывается, что антиминс на белом полотне был священнодействован 2 декабря 1600 года9.

Вознесенская церковь была двухэтажной. На втором этаже было два престола: «по летнюю сторону» Святого Пророка Илии (антиминс на белом полотне 1760 года) и «по южную сторону» великомученицы Параскевы (антиминс на белом полотне 1752 года) ${ }^{10}$.

Описания начала XIX века дают представление о размерах церкви, её устройстве и архитектуре: «На верху той церкви один кумпал и пять глав чешуйчатых с крышками деревянными котораи в вышину 17 сажень Со олтарём и папертью длины восемь сажень а ширины 5 сажень у оной в паперти имеются три крыльца и три двери простой работы... в паперти три окна... окончины стеклянные... С южной стороны два окна в них окончины слудяные. Севера два окна в них окончины слудяные... в олтаре два окна в них окончины слудяные» ${ }^{11}$. Имеется описание второго этажа церкви: «Над церковью вознесения Господня два предела. Церковь святого Пророка Божия Илии и святыя Великомученицы Параскевы. С паперти в оную церковь лестница из паперти Вознесения Господня в паперти два окна окончины стекольчаты, у церкви двери работы простой, на крюках и петлях железных... на дверях образ Святыя Великомученицы Параскевы в церкви 4 окна окончины стеклянные, во олтарях по одному окну, окончины Стеклянные ${ }^{12}$. Таким образом, всего восемь окон на первом этаже и восемь окон на втором по 4 окна с южной и западной сторон»13. Церковь имела алтарь «в два полукружия», для входа в паперть «крыльцо деревянное и над оным Крышка на три Ската» ${ }^{14}$.

Таков был первоначальный облик Вознесенской церкви. Именно в таком виде она и реставрирована в музее «Малые Корелы». В целом пропорции и формы Вознесенской церкви соответствуют архитектуре традиционных для Поморья и Поонежья кубоватых храмов. Главная её особенность - это наличие двух этажей (рис. 2, 3).

Паперть Вознесенской церкви была воссоздана по следам на стенах и по историческим описаниям. Разумеется, её облик во многом гипотетичен. Тем не менее ценность воссоздания первоначального облика в том, что перед нами предстает вариант двухэтажного четверикового в основании храма с кубоватым завершением [7, с. 108-110]. Кубоватые храмы были в подавляющем большинстве одноэтажными. Кроме Вознесенской церкви в Кушереке известна только одна кубоватая двухэтажная церковь - Сретенская в селе Чекуеве (1677) [8, с. 116]. Двухэтажные церкви мы чаще встречаем в городах, где плотная застройка способствует формированию зданий, компактных в плане и высоких в объёме. Не исключено, что устройство кушерецкой Вознесенской церкви несёт городские влияния.

Молитвенное помещение и алтари второго этажа находились в габаритах четверика и, соответственно, были очень тесны. Судя по описанию, полы на втором этаже были сделаны из отёсанных плах, а потолок в алтарях был низкий ${ }^{15}$. Устройство верхнего храма вполне соответствовало древним примерам небольших деревянных церквей, где кафоликон и алтарь находились в одном срубе и отделялись друг от друга перегородками. Подобных храмов известно немного, и все они относятся к XVI - началу XVII века [9, с. 85-93]. Это Троицкая церковь XVI века в Свияжске, Никольская церковь (1602) бывшего Муезерского монастыря, Петропавловская церковь (1601) в Повенце, церковь Казанской иконы Божьей Матери начала XVII века в деревне Юрино Нижегородской области. Очевидно, что компоновка храма в едином прямоу-

\footnotetext{
${ }^{4}$ ГААО. Ф. 462. 0п. 1. Д. 2. Л. 333. Клировые ведомости о церквях первого Благочиния за 1846-1849 (ведомость за 1849 год).

${ }_{5}^{5}$ ГААО. Ф. 104. Оп.1. Д. 991. Л. 2. Ведомости о состоянии православия и раскола в Кушерецком приходе, 1889-1897.

${ }^{6}$ Там же.

7 ГААО. Ф. 104. 0п.1. Д. 922. Л. 1; 8. Клировые ведомости 1845-1907 (ведомости 1845 и 1850 годов).

${ }^{8}$ ГААО. Ф. 104. 0п. 1. Д. 922. Л. 12. Клировые ведомости 1845-1907 (ведомость1876 года).

${ }^{9}$ ГААО. Ф. 29. 0п. 37. Д. 8. Л. 220. Клировая ведомость, 1799.

${ }^{10}$ ГААО. Ф. 29. 0п. 37. Д. 8. Л. 220. Клировая ведомость, 1799.

${ }^{11}$ ГААО. Ф. 29. Оп. 31. Д. 148. Л. 393. Опись церковного имущества по Онежской округе, 1808.

${ }^{12}$ ГААО. Ф. 29. 0п. 31. Д. 176. Л. 102. Опись церковного имущества по Онежской округе, 1814.

${ }^{13}$ ГААО. Ф. 29. Оп. 31. Д. 763. Л. З. Главная опись церковного и ризничного имущества Вознесенской церкви Кушерецкого прихода Онежского Уезда, 1856.

${ }^{14}$ ГААО. Ф. 29. 0п. 31. Д. 258. Л. 142. Опись церковного имущества по Онежской округе, 1829.

${ }^{15}$ ГААО. Ф. 104. 0п.1. Д. 971. Л. 2. Переписка с Архангельской Духовной консисторией, благочиниями, священниками I благочиния, с Онежским уездным исправником, волостными старшинами, с комитетами различных обществ, 1881-1917.
} 
гольном срубе относится к древним традициям деревянного храмового строительства.

Кроме Вознесенской церкви в Кушереке был второй храм - Успения Пресвятой Богородицы. В Клировой ведомости 1799 года указывается дата освящения антиминса на белом полотне Архиепископом Холмогорским и Важским - 3 августа 1700 года ${ }^{16}$. Имя архиепископа трудночитаемо, но известно, что с 1682 по 1702 год архиепископом был Афанасий ${ }^{17}$, в августе 1700 года принимавший непосредственное участие и содействовавший распоряжениям Петра I в войне со Швецией ${ }^{18}$. Дата освящения антиминса может свидетельствовать как о начале строительства церкви, так и о его завершении. Церковь упоминается в документах 1803 и 1810 годов $^{19}$. Сохранилось описание размеров Успенской церкви 1808 года: «Старая церковь Успения Божией Матери деревянная тёплая вышиной 10 сажень а длиною 15 сажень с папертью а шириной 5 сажень Кумпал чешуйчатый. Ободной Главе Крест осьмиконечныой При оной церкви паперть въ паперти одно окно окончина слудяна у трапезы двери простой работы... трапезы три окна в них окончины слудяные... В Церкви 4 окна окончины стеклянные... во алтаре два окна в них окончины стекольчаты. Везде решётки на окнах» ${ }^{20}$. Церковь Успения Пресвятой Богородицы сгорела в первой четверти XIX века.

Судя по описанию, это был четвериковый в основании храм с обширной трапезной. Верх в виде «кумпала» с достаточной уверенностью можно истолковать, как кубоватый верх. Иных вариантов в архитектуре Поморья XVIII века мы не знаем. Одноглавое завершение куба - явление нечастое. Одноглавыми были Пятницкая церковь в селе Шуерецком последней трети XVIII века [10, с. 145-146], церковь Алексия человека Божьего 1721 года в урочище Куртяево, Никольская церковь 1824 года в деревне Унежме [11, с. 201-210]. 0дноглавой была Сретенская церковь в деревне Малошуйке ${ }^{21}$. Вырисовывается некий круг кубоватых одноглавых храмов,

${ }^{16}$ ГААО. Ф. 29. 0п. 37. Д. 8. Л. 220. Клировая ведомость, 1799.

${ }^{17}$ Верюжский В.М. Афанасий, архиепископ Холмогорский. Его жизнь и труды в связи с историей Холмогорской епархии за первые 20 лет её существования. СПб., 1908. С. 487 (http://webirbis.aonb.ru/irbisdoc/kr/2015/07kp103/11/index.html\#zoom=z).

${ }^{18}$ Там же. С. 540 (http://webirbis.aonb.ru/irbisdoc/kr/2015/07kp103/552/index.html).

${ }^{19}$ ГААО. Ф. 29. 0п. 37. Д. 26. Л. 151. Клировая ведомость, 1803; Ф. 29. 0п. 35. Д. 5. Л. 432. Клировые ведомости церквей г. Архангельска, Архангельского, Кемского, Мезенского, Онежского, Пинежского, Холмогорского и Шенкурского уездов, 1810.

${ }^{20}$ ГААО. Ф. 29. 0п. 31. Д. 148. Л. 397. Опись церковного имущества по Онежской округе, 1808.

${ }^{21}$ ГААО. Ф. 29. Оп. 31. Д. 193. Л. 177-178. Опись церковного имущества по Онежской округе, 1819.

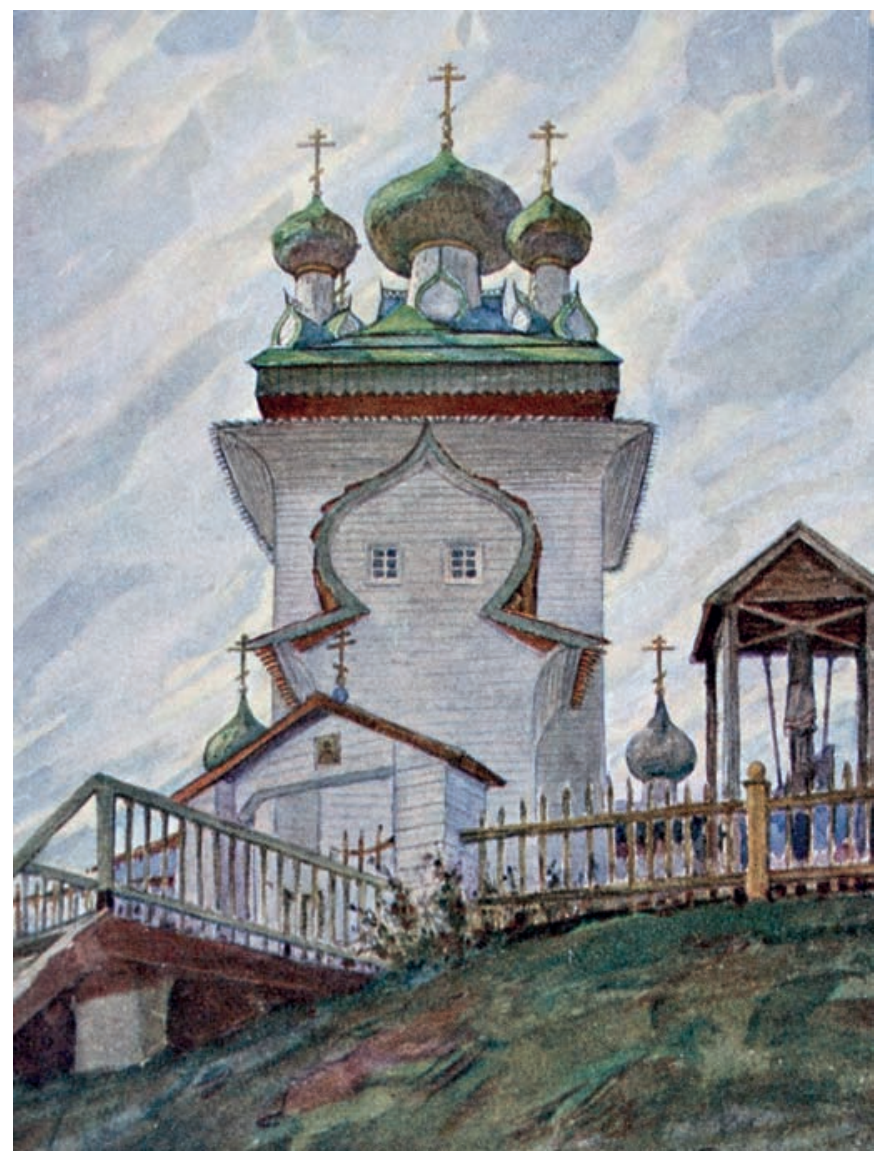

Рис. 4. Вознесенская церковь в селе Кушерека. Акварель В. Плотникова. Открытка начала XX века

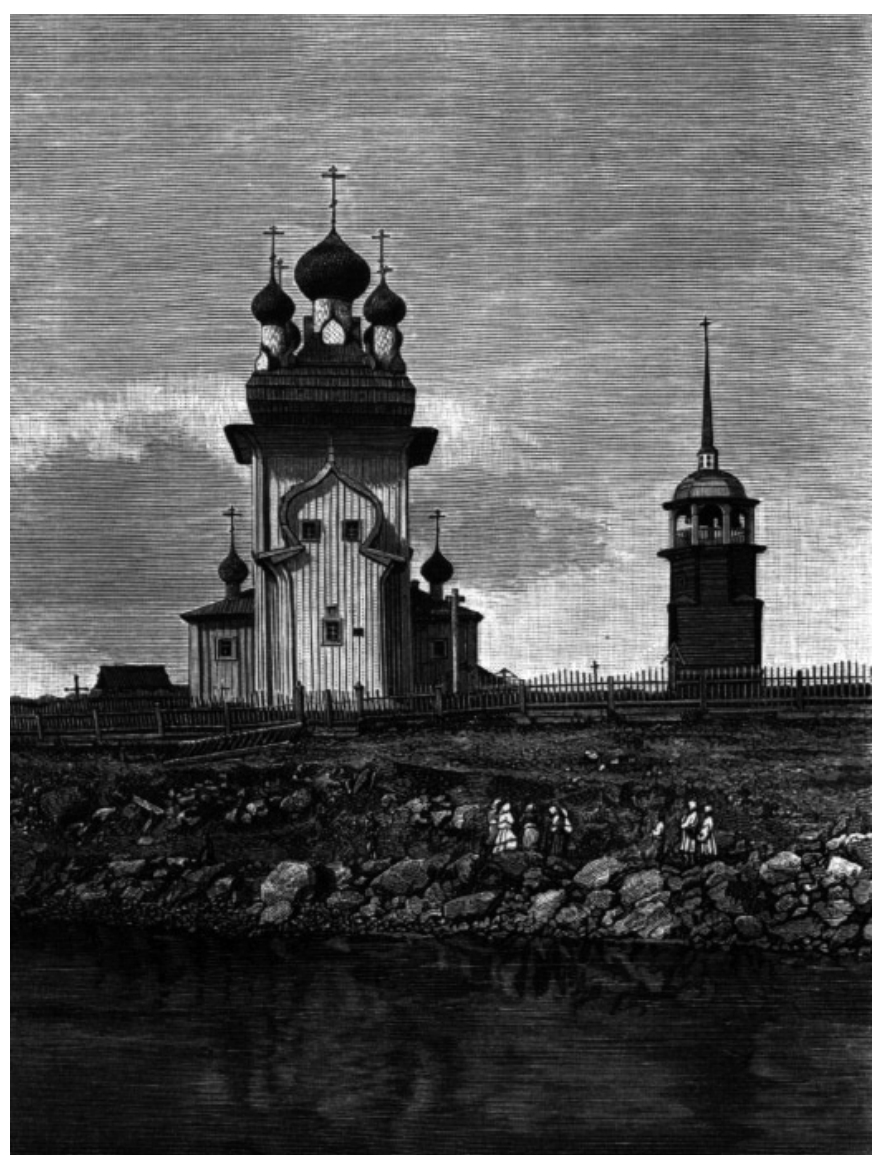

Рис. 5. Вознесенская церковь и колокольня в селе Кушереке. Гравюра В.В. Суслова. Конец ХIХ века 
распространённых в районе Поморского берега. Похоже, что в него вписывается и Успенская церковь в Кушереке.

После того, как сгорела Успенская церковь, Вознесенская церковь в 1825 году была значительно реконструирована. Паперть и крыльцо разобрали и вместо них к церкви пристроили теплую двухэтажную трапезную 15 сажень в длину по фундаменту 22 . Имеется документ, в котором указано, что 16 июля 1825 года в Архангельской Духовной консистории был заслушан рапорт дьякона Онежского Троицкого Собора Василия Ядохина о наличии «при нём» четырёх новых освящённых антиминсов: «1 Малошуйскаго прихода Сретенской церкви, 2 Нименскаго прихода Благовещения пресвятой Богородицы, 3 Ворзогорского святителя Николая Чудотворца, 4 Кушерецкаго Вознесения Господня» ${ }^{23}$. Принято решение: «Антиминсы отдать в церкви с роспискою о получении им денег» ${ }^{24}$. Вероятно, антиминс был получен на строительство тёплой церкви (трапезы). К 1827 году к трапезе были пристроены два «отруба»: «один съ южной Страны для Олтаря къ приделу Успения Божия Матери, а другой съ Северной Страны для кладовой» 25 Трапеза имела шесть окон, «три Главы обиты чешуёю, Кресты осьмиконечные деревянные» ${ }^{26}$. Придел Успения Божьей Матери был освящён в 1830 году протоиреем Онежского Собора Иоанном Тамицким ${ }^{27}$. Позже из кладовой был сделан придел во имя Богоявления Господня и освящён в 1860 году членом Консистории, Архангельской Градской Рождественской Церкви священником Алексием Васильевым ${ }^{28}$. К 1856 году «осьмерня съ пятью главами, которая покрыта крышей деревянной окрашена Красною Краскою, а Главы окрашены медянкою» 29.

В 1872 году планировалось «исправить» церковь, для этого в рапорте губернского архитектора Кармина уточнялось, что для выполнения предписания Губернского правления от 30 сентября под номером 473, требуется «количество беревен на исправление церкви потребно 96,6 деревьев, а на устройство ограды 193,04»30. Какие именно работы планировалось провести - не уточнялось. Известно, что в 1874 году церковь была обшита тёсом и побелена мелом ${ }^{31}$.
В 1874 году был утрачен антиминс с престола Святого Пророка Божия Илии 32.18 октября 1876 году вышел приказ № 3604 об исключении антиминса с престола Святого Пророка Божия Илии из Церковной описи ${ }^{33} .25$ августа 1881 года церковный староста Кушерецкого прихода Панкратий Кучин пишет прошение о переделке алтаря и создании единого престола святого Пророка Божия Илии и святой великомученицы Параскевы Пятницы на втором этаже Вознесенской церкви.

В Вознесенской церкви предполагалось помещение алтаря вынести на восток, расположив его в пространстве покрывавшей алтарный прируб бочки. Это решение, в отличие от старого устройства верхнего этажа, было совершенно необычное для традиционных деревянных храмов. На торцевой стене алтаря в бочке было прорублено два окна (рис. 4). 1 января 1882 года вышел указ № 3486 Архангельской Духовной Консистории о перестройке алтаря и устройстве нового престола во имя двух святых ${ }^{34}$. Вновь ремонтированный престол был освящён 27 октября 1883 года Онежским благочинным священником Иаковом Димитриевым-Сабариным, антиминс на синем атласе был освящён и подписан Серапионом Епископом Архангельским и Холмогорским ${ }^{35}$.

Таким образом, в Вознесенской церкви стало четыре престола: Вознесения Господня (антиминс 1669 года) на первом этаже, на втором этаже - Святого Пророка Божия Илии и святой великомученицы Параскевы (освящён в 1883 году), в теплой церкви (трапезе) - Успения Божией матери (освящен в 1830 году) и Богоявления Господня (освящен в 1860 году).

Подробное описание храма 1894 года даёт представление о позднейшем облике Вознесенской церкви, утраченном в результате реставрации и перевозке в музей: «Над церковью возвышается четырёхугольный деревянный кумпол, покрытый ввиде чешуи, окрашен зелёною краскою, а блюдо его - красною, с пятью главами; над трапезой крыша на два ската, покрыта досками, выкрашенными красной краской со смолою; ниже сей крыши идёт крыша над пристройками съ обеих сторон на один скат; крытая досками без окраски; над трапезой и над предельными алтарями находится по одной главе; все главы

\footnotetext{
22 ГААО. Ф. 104. 0п.1. Д.922. Л. 1. Клировые ведомости 1845-1907 (Ведомость 1845 года).

${ }_{23}^{2}$ ГААО. Ф. 478. 0п. 1. Д. 2. Л. 16. Указы Архангельской Духовной консистории и 0нежского духовного правления, $1824-1827$.

${ }^{24}$ Там же.

${ }^{25}$ ГААО. Ф. 29. 0п. 31. Д. 258. Л. 142. Опись церковного имущества по Онежской округе, 1829.

${ }^{26}$ Там же.

${ }^{27}$ ГААО. Ф. 104. 0п.1. Д. 922. Л. 8 Клировые ведомости 1845-1907 (ведомости 1870 года).

${ }^{28}$ Там же.

${ }^{29}$ ГААО. Ф. 29. 0п. 31. Д. 763. Л. 3. Главная опись церковного и ризничного имущества Вознесенской церкви Кушерецкого прихода Онежского Уезда, 1856.

${ }^{30}$ ГААО. 75. 0п. 1. Д. 456. Л. 7. Дело о рассмотрении проекта и сметы на исправление Кушерецкой церкви 0нежского уезда 28 марта - 4 апреля 1872.

${ }^{31}$ ГААО. Ф. 104. Оп.1. Д. 922. Л. 12. Клировые ведомости 1845-1907 (ведомости 1876 года).

32 ГААО. Ф. 104. 0п.1. Д. 922. Л. 52. Клировые ведомости 1845-1907 (ведомости 1879 года).

${ }^{3}$ ГААО. Ф. 104. 0п.1. Д. 971. Л. 2. Переписка с Архангельской Духовной консисторией, благочиниями, священниками I благочиния, с Онежским уездным исправником, волостными старшинами, с комитетами различных обществ, 1881-1917.

${ }^{34}$ ГААО. Ф. 104. 0п.1. Д. 971. Л. 5. Переписка с Архангельской Духовной консисторией, благочиниями, священниками I благочиния, с 0нежским уездным исправником, волостными старшинами, с комитетами различных обществ, 1881-1917.

35 ГААО. Ф. 104. 0п.1. Д. 922. Л. 52. Клировые ведомости 1845-1907 (ведомости 1885 года).
} 
деревянныя, чушуёю, увенчаны деревянными же крестами, окрашенными жёлтою краскою, самые же главы окрашены зелёною краскою, а шейки их охрою. Главный Алтарь закрыт крытым ввиде чешуи кумпалом на два ската, окрашенным зелёною краскою, без главы и креста... С северной стороны храма приделано церковное крыльцо, ход на него с двух сторон, съ третьей стороны находятся перила; крыльце закрыто крышей на два ската, деревянной, выкрашенной красной краской со смолою, поддерживается она двумя столбами» ${ }^{36}$.

В 1897 году были поставлены новые иконостасы в Успенском и Богоявленском приделах ${ }^{37}$, в 1898 году в главном Вознесенском храме был возобновлён иконостас ${ }^{38}$. Ведомость 1907 года свидетельствует: «в этом году обшиты стены и окрашены белилами» ${ }^{39}$.

При Вознесенской церкви была отдельно стоящая колокольня. Можно предположить, что время её строительства близко ко времени возведения церкви. Колокольня имела «вышину оной 8 сажень на ней 4 колокола» ${ }^{40}$. Более поздние документы также указывают на шатровый верх колокольни ${ }^{41}$. В 1854 году вместо прежней колокольни была построена новая. Указывается, что старая колокольня была ветхая, что косвенно свидетельствует о том, что она была построена в конце XVII - первой половине XVIII века.

Новая колокольня была покрыта «крышей деревянной повыше звоновъ и до креста окрашена Красною краскою»².

${ }^{36}$ ГААО. Ф. 29. 0п. 31. Д. 1579. Л. 3-4. Клировая ведомость Кушерецкого прихода Онежскаго Уезда, 1894.

${ }^{37}$ ГААО. Ф. 104. 0п.1. Д. 922. Л. 62. Клировые ведомости, 1845-1907 (ведомость 1897 года).

38 ГААО. Ф. 104. 0п.1. Д. 922. Л. 65. Клировые ведомости, 1845-1907 (ведомость 1898 года).

${ }^{39}$ ГААО. Ф. 104. 0п.1. Д. 922. Л. 67. Клировые ведомости, 1845-1907 (ведомость 1907 года).

40 ГААО. Ф. 29. 0п. 31. Д. 148. Л. 401. Опись церковного имущества по Онежской округе, 1808.

${ }^{41}$ ГААО. Ф. 29. 0п. 31. Д. 176. Л. 106. 0пись церковного имущества по Онежской округе 1814; Ф. 29. 0. 31. Д. 258. Л. 150об. Опись церковного имущества по Онежской округе, 1829.

42 ГААО. Ф. 29. 0п. 31. Д. 763. Л. 16. Главная опись церковного и ризничного имущества Вознесенской церкви Кушерецкого прихода Онежского Уезда, 1856.



Рис. 6. Вознесенская церковь и колокольня. Село Кушерека. Фото начала ХХ века (источник: [10])
Колокольня была выстроена с разрешения Преосвященнаго Варлаама, Епископа Архангельсаго и Холмогорскаго, в два яруса, в 13 саженей вышины со шпилем ${ }^{43}$. В 1874 году сделана деревянная ограда вокруг колокольни и Вознесенской церкви ${ }^{44}$. В 1881 или 1882 году купол и крест на колокольне был окрашен желтой краской, а в 1885 - зелёной ${ }^{45}$. Купола церквей и колоколен Онежского Поморья обычно окрашивались в зелёный цвет. Данные о жёлтом цвете купола нам встретились впервые. Первоначально колокольня была не обшита (рис. 5), что подтверждается и отсутствием в документах информации о покраске стен. В документе 1894 года встречается подробное описание колокольни, в котором указывается о покраске купола, шпиля и креста: «Колокольня деревяная построена отдельно от церкви в 3-х саженях с северной стороны, в 2 яруса, закрытая кумполом, заканчивается шпилем с таким же крестом, кумпал и шпиль окрашены зелёною краскою, а крест жёлтой; у звонов восемь пролётов и между ними деревянные перила. Высота колокольни со шпилем 13 саж., а до звонов 8 саж. К колокольне с восточной стороны пристроено крыльцо, крытое тёсом, въ колокольне три деревянные лестницы. Два окна, двои двери: одни внутрь колокольни, а другие в кладовую, которая помещается в другой части края колокольни. Колоколов 6-ть» ${ }^{46}$. В 1898 году колокольня была обшита тёсом и окрашена белилами на масле ${ }^{47}$ (рис. 6).

Рассматривая Вознесенскую церковь в Кушереке, нельзя не упомянуть о часовнях. Наличие большого количества старообрядцев не могло не оказать влияние на типологию и устройство зданий. На территории Онежского Поморья распространены избы-часовни, которые можно сопоставить с отдельно стоящими трапезными [12, с. 17-27]. В селе Кушерека сначала не было кладбищенской часовни. Это могло быть связано с опасением использования часовни в качестве старообрядческой. В 1843 году вышел указ Арханельской Духовной консистории о погребении умерших раскольников в отведённых отдалённых местах при общем кладбище и запрете на устройство «часовен и молитвенных домов на сих кладбищах $\gg^{48}$. Кроме этого, требовалось «иметь строжайшая наблюдения», чтобы крестьянские избы не были обращены в «публичные моления», а в уже существующих часовнях «небыли устроены Престолы, как принадлежность Православныя Церквей С нарушителями сего поступать по законам. Престолов устроенных уже прежде в Часовнях, коих существование дозволено было на основании законов, не уничтожать» ${ }^{49}$.

${ }^{43}$ ГААО. Ф. 104. 0п.1. Д. 922. Л. 12. Клировые ведомости 1845-1907 (ведомость 1876 года).

44 ГААО. Ф. 104. 0п.1. Д. 922. Л. 30. Клировые ведомости 1845-1907 (ведомость 1879 года).

45 ГААО. Ф. 104. 0п.1. Д. 922. Л. 46; 51. Клировые ведомости 1845-1907 (ведомости за 1882 и 1885 года).

46 ГААО. Ф. 29. 0п. 31. Д. 1579. Л. 31. Клировая ведомость Кушерецкого прихода Онежскаго Уезда, 1894.

47 ГААО. Ф. 104. 0п.1. Д. 922. Л. 65. Клировые ведомости, 1845-1907 (ведомость 1898 года).

48 ГААО. Ф. 478. 0п. 1. Д. 8. Л. 19. Указы Архангельской Духовной консистории и Онежского духовного правления, 1843-1846.

${ }^{49}$ Там же. 
Кладбищенская часовня в Кушереке была построена только в 1912 году из 250 брёвен ${ }^{50}$. Согласно смете на лесные материалы, часовня была рублена в лапу, имела паперть с колокольней, барабан, один купол, односкатное крыльцо ${ }^{51}$. По описанию часовня схожа с кладбищенскими часовнями, перестроенными в церкви, - Тихвинской иконы Божьей матери в деревне Юдмозеро, Зосимы и Савватия в селе Ворзогоры. По воспоминаниям местных жителей, часовню не достроили и разобрали.

Таким образом, в архитектуре Вознесенской церкви, кроме местных особенностей, мы находим много параллелей и взаимосвязей с деревянной храмовой архитектурой всей страны. Четвериковые в основании высокие храмы представляют собой тип, распространённый в разных регионах России. Если в Поморье и на Онеге они завершаются кубами, как Вознесенская церковь, то в Пинежско-Мезенском крае они завершаются шатрами на крещатой бочке, в северо-западных бывших новгородских землях - восьмискатными крышами.

Кубоватые завершения северорусских деревянныххрамов сопоставимо с московской и среднерусской архитектурой каменных храмов XVII века [13, с. 52-62]. Их роднит декоративный, насыщенный пластикой верх и пятиглавие. Эти особенности характерны для всей русской храмовой архитектуры XVII века.

И, наконец, устройство компактного храма на втором этаже Вознесенской церкви погружает нас в древность и свидетельствует о взаимосвязях деревянного храмового зодчества Поморья и общерусскими традициями деревянной архитектуры.

\section{Лuтература}

1. Бодэ, А.Б. Древние новгородские влияния в деревянном зодчестве северо-западных областей XVI-XVIII веков / А.Б. Бодэ // Academia. Архитектура и строительство. - 2014. №1. - C. 50-54.

2. Мильчик, М.И. Древнерусская иконография монастырей, храмов и городов XVI-XVIII веков : Статьи 1973-2017 / М.И. Мильчик. - СПб : Коло, 2017. - 378 с.

3. Бодэ, А.Б. Деревянное храмостроительство нижнего Поонежья XIX - начала XX века / А.Б. Бодэ, Е.В. Ходаковский // Academia. Архитектура и строительство. - 2020. - № 2. - С. 31-39.

4. Терентьева, А.А. Собор Воскресения Христа. К вопросу о реконструкции архитектурного облика / А.А. Терентьева // Деревянное зодчество. Новые материалы и открытия. Вып. IV / под ред. А.Б. Бодэ. - М. ; СПб : Коло, 2015. - C. 208-228.

5. Ополовников, А.В. Русское деревянное зодчество : Памятники шатрового типа. Памятники клетского типа и малые архитектурные формы. Памятники ярусного, кубоватого

${ }^{50}$ ГААО. Ф. 104. 0п.1. Д. 1016. Л. 4. Сдаточно-приёмные акты священников-настоятелей Кушерецкого прихода. 1898-1912.

${ }^{51}$ ГААО. Ф. 104. 0п.1. Д. 1033. Л. 2. Смета на лесные материалы, необходимые для постройки в Кушерецком приходе кладбищенской церкви, 1911. и многоглавого типа / А.В. Ополовников. - М. : Искусство, 1986. - 310 c.

6. Крохин В.A. Реставрация Вознесенской церкви в селе Кушерека Архангельской области / В.А. Крохин // Архитектурное наследие и реставрация. Реставрация памятников истории и культуры России. Вып. 3. - М., 1988. - С. 59-70.

7. Орфинский, В.П. Типология деревянного культового зодчества Русского Севера / В.П. Орфинский, И.Е. Гришина. - Петрозаводск : Издательство ПетрГУ, 2004. - 280 с.

8. Ущаков, Ю.С. Ансамбль в народном зодчестве русского Севера / Ю.С. Ушаков. - Л. : Стройиздат, 1982. - 168 с.

9. Шургин, И.Н. Деревянные церкви первой половины XVII века без алтарного прируба / И.Н. Шургин // XVII век в истории и культуре Русского Севера / науч. ред. Н. И. Решетников ; сост. Н. И. Тормосова. - Каргополь : Каргопольский государственный историко-архитектурный и художественный музей, 2012. - С. 85-93.

10. Забелло, С. Русское деревянное зодчество / С. Забелло, В. Иванов, П. Максимов. - М. : Государственное архитектурное издательство Академии архитектуры СССР, 1942. - 288 с.

11. Федосеева, E.E. Архитектурный ансамбль Унежемского прихода / Е.Е. Федосеева // Деревянное зодчество. Новые исследования и открытия. Вып. I / под ред. А. Б. Бодэ. - М. ; СПб. : Коло, 2010. - С. 201-226.

12. Бодэ, А.Б. Церковь Тихвинской иконы Божьей Матери в деревне Юдмозеро Архангельской области. История и архитектура / А.Б. Бодэ, Т.В. Жигальцова // Studia Humanitatis Borealis. - 2020. - № 3. - С. 17-27.

13. Шургин, И.Н. 0 возможных путях образования кубоватой формы завершения деревянных храмов / И.Н. Шургин // Ильинский Водлозерский погост: история, архитектура, эстетика, этнография / под ред. А. В. Пигина. - Петрозаводск : Издательство ПетрГУ, 2009. - С. 52-62.

\section{References}

1. Bode A.B. Drevnie novgorodskie vliyaniya v derevyannom zodchestve severo-zapadnykh oblastei XVI-XVIII vekov Ancient Novgorod influences in the wooden architecture of the north-western regions of the 16th - 18th centuries]. In: Academia. Arkhitektura istroitel'stvo [Academia. Architecture and construction], 2014, no. 1, pp. 50-54. (In Russ., abstr.in Engl.)

2. Mil'chik, M.I. Drevnerusskaya ikonografiya monastyrei, khramov i gorodov XVI-XVIII vekov: Stat'i 1973-2017 [Old Russian Iconography of Monasteries, Churches and Cities of the 16th - 18th Centuries. Articles 1973-2017]. St. Petersburg, Kolo Publ., 2017, 378 p. (In Russ.)

3. Bode A.B., Khodakovskii E.V. Derevyannoe khramostroitel'stvo nizhnego Poonezh'ya XIX - nachala XX veka [Wooden temple-building of the lower Ponezhie of the XIX - early XX century]. In: Academia. Arkhitektura i stroitel'stvo [Academia. Architecture and construction], 2020, no. 2, pp. 31-39. (In Russ., abstr.in Engl.)

4. Terent'eva A.A. Sobor Voskreseniya Khrista. K voprosu o rekonstruktsii arkhitekturnogo oblika [Cathedral of the 
Resurrection of Christ. On the question of the reconstruction of the architectural appearance]. In: Derevyannoe zodchestvo. Novye materialy i otkrytiya [Wooden architecture. New materials and discoveries], Iss. IV, A.B. Bode (ed.). Moscow, St. Petersburg, Kolo Publ., 2015, pp. 208-228. (In Russ.)

5. Opolovnikov A. V. Russkoe derevyannoe zodchestvo : Pamyatniki shatrovogo tipa. Pamyatniki kletskogo tipa i malye arkhitekturnye formy. Pamyatniki yarusnogo, kubovatogo i mnogoglavogo tipa [Russian wooden architecture: Monuments of the tent type. Monuments of the cage type and small architectural forms. Monuments of tiered, cubic and multiheaded type]. Moscow, Iskusstvo Publ., 1986, 310 p (In Russ.)

6. Krokhin V.A. Restavratsiya Voznesenskoi tserkvi v sele Kushereka Arkhangel'skoi oblasti [Restoration of the Ascension Church in the village of Kushereka, Arkhangelsk Region]. In: Arkhitekturnoe nasledie i restavratsiya. Restavratsiya pamyatnikov istorii i kul'tury Rossii [Architectural heritage and restoration. Restoration of monuments of history and culture of Russia], Iss. 3. Moscow, 1988, pp. 59-70. (In Russ)

7. Orfinskii V.P., Grishina I.E. Tipologiya derevyannogo kul'tovogo zodchestva Russkogo Severa [Typology of wooden cult architecture of the Russian North]. Petrozavodsk, PetrSU Publishing House, 2004, 280 p. (In Russ)

8. Ushakov Yu. S. Ansambl' v narodnom zodchestve russkogo Severa [Ensemble in the folk architecture of the Russian North]. Leningrad, Stroiizdat Publ., 1982, 168 p. (In Russ)

9. Shurgin I. N. Derevyannye tserkvi pervoi poloviny XVII veka bez altarnogo priruba [Wooden churches of the first half of the 17th century without an altar cut]. In: XVII vek $v$ istorii $i$ kul'ture Russkogo Severa [XVII century in the history and culture of the Russian North], N.I. Reshetnikov (sc.ed.), N.I. Tormosova (comp.). Kargopol', Kargopol State Historical, Architectural and Art Museum, 2012, pp. 85-93. (In Russ)

10. Zabello S., Ivanov V., Maksimov P. Russkoe derevyannoe zodchestvo [Russian wooden architecture]. Moscow, State Architectural Publishing House of the Academy of Architecture of the USSR, 1942, 288 p. (In Russ)

11. Fedoseeva E. E. Arkhitekturnyi ansambl' Unezhemskogo prikhoda [The architectural ensemble of the Unezhemsky parish]. In: Derevyannoe zodchestvo. Novye issledovaniya $i$ otkrytiya [Wooden architecture. New research and discoveries]. Iss. I, A.B. Bode (ed.). Moscow, St. Petersburg, Kolo Publ., 2010, pp. 201-226. (In Russ)

12. Bode A.B., Zhigal'tsova T.V. Tserkov' Tikhvinskoi ikony Bozh'ei Materi v derevne Yudmozero Arkhangel'skoi oblasti. Istoriya i arkhitektura [Church of the Tikhvin Icon of the Mother of God in the village of Yudmozero, Arkhangelsk Region. History and architecture]. In : Studia Humanitatis Borealis. 2020. № 3. - S. 17-27.

13. Shurgin I. N. 0 vozmozhnykh putyakh obrazovaniya kubovatoi formy zaversheniya derevyannykh khramov [Possible ways of forming a cubic form of completion of wooden temples]. In: Il'inskii Vodlozerskii pogost: istoriya, arkhitektura, estetika, etnografiya [Ilyinsky Vodlozersky Pogost: history, architecture, aesthetics, ethnography], A.V. Pigin (ed.). Petrozavodsk, PetrSU Publishing House, 2009, pp. 52-62. (In Russ) 